PLENUM: TRACKING THE FRONTIERS

\section{VIDEO MICROSCOPY}

\section{by Shinya Inoué}

A practical handbook for those getting started in video microscopy. The basics of both video and microscopy are reviewed and sufficient theory is provided to aid in the selection and use of video microscopy equipment. A list of hard-to-find pamphlets-along with the addresses of their sources-and a glossary-with relevant section numbers included for each entry-are among the many features that make this a valuable reference as well as a practical handbook.

0-306-42120-8/528 pp. + index/ill./1986 $\$ 65.00$ (\$78.00 outside US \& Canada) text adoption price on orders of six or more copies: $\$ 37.50$

\section{LEARNING ABOUT ENERGY by David J. Rose}

A wide-ranging text for senior and graduate students that weaves technical and scientific information into an integrated current account of the field, including energy in its social and economic contexts, environmental consequences of energy use, energy conservation, fossil fuel resources and reserves, coal, nuclear power, solar power, and global electrification. A volume in the series Modern Perspectives in Energy.

0-306-421240/484 pp. + index/ill./1986 $\$ 59.50$ ( $\$ 71.40$ outside US \& Canada) text adoption price on erders of six or more copies: $\$ 39.50$

\section{HYBRIDOMA TECHNOLOGY IN THE BIOSCIENCES AND MEDICINE \\ edited by Timothy A. Springer}

"Altogether this is an interesting volume, containing much useful reference material about new ways to produce and improve monoclonal antibodies." -Nature

0-306-41996-3/628 pp./ill./1985

$\$ 75.00$ (\$90.00 outside US \& Canada)

text adoption price on orders of six or more copies: $\$ 45.00$

\section{MOLECULAR AND CELLULAR MECHANISMS OF ANESTHETICS}

edited by Sheldon $\mathbf{H}$. Roth and Keith W. Miller

This comprehensive collection reports recent progress in this area, summarizes the current situation, and indicates future directions for research.

0-306-42128-3/483 pp. + index/ill./1986

$\$ \$ 9.50$ (\$83.40 outside US \& Canada)

Plenum Publishing Corporation 233 Spring Street

New York, N.Y. 10013

In the United Kingdom: 88/90 Middlesex Street London E1 7EZ, England

Reader Service No.2 cause the seaweeds are compared, bulk for bulk, with volumes of water (which is, after all, wet). Figure 4.12 - illustrating changes in the monthly temperature and salinity coordinates for two locations would have been easier to interpret if the months had been specifically indicated. And I wouldn't have called laminarin a starch, or methane a component of crude oil. These, however, are small matters.

The information and ideas in this book have never before been brought together in such a concise, readable form. The authors are to be congratulated for having accomplished a herculean task (a not inappropriate analogy, by the way, for it was Hercules who finally liberated Prometheus from his cliff).

Ralph Lewin is a Professor of Marine Biology at the Scripps Institution of Oceanography, University of California, La Jolla, California 92093. USA.

\section{Fringe existences}

\section{Stephen Hawkins}

An Introduction to Coastal Ecology. By P.J.S. Boaden and R. Seed. Blackiel Chapman \& Hall:1985. Pp.218. Hbk $£ 19.95, \$ 39.95$; pbk£9.95, \$19.95.

AN INTEGRATED treatment of coastal ecology at undergraduate level has been long overdue. In this book, Boaden and Seed have used their world-wide research and teaching experience to weave together the diverse strands of ecological research on coasts into a generally thorough yet approachable narrative.

The scope is admirably broad, moving from the edge of the continental shelf, via shores and estuaries, to dunes and coastal heath. An introduction to the coastal environment is followed by chapters on coastal habitats and their organisms: rocks, sediments, brackish waters, coral reefs, marshes and mangroves are all well covered, with "Other Coastal Habitats" completing this part of the text. The book finishes by dealing concisely and interestingly with inshore resources, seabirds and coastal management. A comprehensive bibliography lists key papers and reviews.

The book's balance, tilted towards marine ecosystems and animals, reflects the interests of the authors and there is, perhaps, not enough on the terrestrial systems consigned to "Other Coastal Habitats". Perhaps, too, the initial description of the coastal environment could have stressed its characteristic features more strongly. The sharp environmental gradients up and along shores and estuaries, and across dunes, mangroves and marshes, are insufficiently emphasized; for example, the time spent in or out of water at various tidal levels is relegated to a pa-

\section{IMAGE \\ UNAVAILABLE FOR COPYRIGHT REASONS}

Atlantic puffin (Fratercula arctica). The picture is taken from The Atlantic Alcidae, published by Academic price hbk $£ 34, \$ 40$; pbk $£ 16.50, \$ 19.95$.

ragraph under the subtitle "Seiches". The variability and unpredictability of coastal systems could also have been highlighted, and it would have been helpful if the different accounts of habitats and organisms had been drawn together in a synoptic overview. Conversely, the authors have done well to bring the study of seabirds into the marine biological mainstream, while the chapter on the neritic province provides a description of basic biological oceanography which beginners will find particularly illuminating.

This is a useful textbook which is easy to read and understand. It should be helpful to non-biologists interested in coastal processes, and will be appreciated by undergraduates embarking on options or field courses in marine ecology; certainly, it provides a firm basis for subsequent, more advanced reading. My opinion of the book is best summed up by the fact that I have adopted it for my own course on coastal marine biology.

Stephen Hawkins is a Lecturer in the Department of Zoology, University of Manchester, Manchester M139PL, UK. 